After 48 hours there was usually one colony in the Agar Plate, and the roo c.c. solution went usually acid, but never the 25 c.c. Unfortunately, neither of the storage tanks were covered, and as these tests were done in the water from the main, it was the cause of this slight unsterility, tests done in water taken from No. 3 tap (half-hour's contact) gave perfectly sterile results. This goes to prove that in such a climate as England 0.75 parts, or even 0.5 parts per $I, 000,000$ would give an absolute germ-free water.

Remarks. - The whole place was beautifully fitted, besides having a spare pump both for settling tanks and another for the storage tanks, also a spare Wallace Tieman apparatus already fitted up, there was a complete set of spares for everything, so that we could have fitted up another set of everything alongside; money seems to have been just thrown away. It was commonly reported that this plant, which could only pump 5,000 gallons an hour, cost, with carriage, etc., over $f 20,000$ (there were 20 installations in Mesopotamia, including barges, only I $_{3}$ of which were ever erected). From a military point of view, they were an absolute waste, as, firstly, the water of Mesopotamia is exceptionally good, and owing to the sparse population and fast-running river, the degree of pollution is small. During the summer and autumn the water is as pure as crystal and requires no filtration, and in the film alum was not used. In the winter and spring the water was easily settled in the field by adding alum to it in a large canvas tank, syphoning off the clear liquid.

The whole plants appeared to be a waste of public money, and a sanitary orderly was the only man necessary who could chlorinate the unit's drinking water morning and evening, and over which a military policeman could be put in charge.

On taking over the plant, the writer found that all the drains from his cook-bouse, etc., had been so placed so as to run down into the river just above the intake; also that Arabs came daily and washed sheepskins not 50 yards above. It was found possible to stop the latter without much difficulty, but the former trouble took longer to remedy.

At the second plant, which I took over just before, leaving the country, the conditions were even worse. With roo yards above the intake were moored hospital boats, on which dysentery cases were carried across the river. At the rear of these was situated a W.C. (the rear of the nearest boat was often within 25 yards of the intake).

$A$ report was sent by the writer to the A.D.M.S. Sanitation three weeks before he left, placing the matter before him, but no action had been taken. The hospital authorities refused to move the boats higher up or lower down, unless ordered to do so by him. Their argument appeared to be this: "What was the use of the elaborate plant if it didn't clear the water of all bacteria?" (this from a medical mian).
The system could be worked quite well on a large scale at home, and would need hardly any attention, the ordinary filter beds being used or duct on the water emerging from the reservoir.

\section{MEMORANDUM ON THE TEACHING OF SEX HYGIENE IN THE PUBLIC ELEMENTARY SCHOOLS. \\ $\mathrm{BY}$ \\ GEORGE F. BUCHAN, M.D., D.P.H., Medical Officer of Health, Willesden.}

THE drain upon human resources occasioned by more than four years of war makes it incumbent upon the Hygienist to examine proposals which suggest, directly or indirectly, means for the restoration and improvement of National Health.

Our stock of National Health is at present low. The birth rate is falling. During the four weeks ended 5 th October, IgI 8 , the birth rate in Willesden was only $\mathbf{I}_{3.24}$ per thousand as against a pre-war rate of 24.70 per thousand in $19 \mathrm{I} 4$, a fall of 46.4 per cent. The medical examination of recruits for the army has revealed the fact that only 36 to 37 per cent. of the male population of military age are " A" men. Such men are suffering most heavily as the result of war and the population therefore more than ever before will have to be carried on by men of lower categories.

The measure of success achieved by the teaching of Sex Hygiene must be judged by improvement in the foregoing conditions. One result should be a rise in the birth rate at least to the pre-war rate. This will only be accomplished if the future education of the girl no longer consists in the concealment from her of the essential facts of life, and if her outlook is so altered that she does not come to regard the racial instincts as low and shameful, The birth rate, however, is not likely to increase to the necessary extent unless it is impressed upon all that the rearing of large and healthy families is national work of the highest importance, and the State in its turn recognises the national character of the work of child bearing.

The teaching of Sex Hygiene includes instruction in the preservation of the health of the sexual organs. One of the results of such teaching, therefore, should be an early diminution in the incidence of venereal diseases, and subsequently an increased proportion of " $A$ " men in the population. Incidentally, some diseases or conditions associated with puberty would disappear or be diminished. For example, masturbation or self-abuse would be lessened. 
Here it should be noted as particularly important that no mention of this subject should be made to a child who already has no knowledge of it. Many girls too would be saved from the shock of the onset of menstruation, while at later ages the various forms of neurosis not uncommonly associated with this cyclic change, such as hysteria, nervousness, or depressionthe result of disordered fancies-would tend to diminish in consequence of healthy knowledge.

These, in brief outline, are some of the main results which the Hygienist would expect to follow more or less rapidly on the education of the young in the matter of the preservation of the health of the reproductive organs. The question arises as to how the subject can be introduced in the ordinary elementary schools. Class teaching has been suggested, but in this connection the main difficulties are that children of different development and widelyvarying knowledge in sex matters are associated in the same class. Individual teaching for those who appear to require it has likewise been advocated, but this latter method would only lead to the instruction of the more obvious cases of abuse, as no teacher can very" well say which children are or are not in need of sex education.

But whether instruction is given collectively or individually, the person by whom it is given is probably the most important single factor in connection with the subject. By some the class teacher is thought to be the right person, by others a special teacher, or the doctor, or the parent. None of these, to my mind, is necessarily the right person. The kind of teacher required for a subject like this is one who is well versed in biology and physiology, and who has the gifts or the training of a teacher. The teacher, too, must be in complete sympathy with the child, and have a full appreciation of the delicacy and difficulty of the subject. Above all, the teacher must have a healthy mind, and the necessary tact for overcoming the inherent difficulties concerned in the enlightenment of the young on matters of Sex Hygiene.

Bearing in mind the views above expressed and the objects to be attained by the teaching of Sex Hygiene, and remembering further that the education of the young in this subject is bound to include in some cases enlightenment in respect of the reproduction of the race, I am. reluctantly impelled to the conclusion that Sex Hygiene as a separate entity cannot at present be included in the curriculum of an ordinary elementary school. I think the most that can be done in elementary schools is the establishment of a graduated course on Nature Study, over a number of years, beginning with Botany and the reproduction of plants, passing on to Zoology and the reproduction of the lower and possibly some of the higher forms of animal life, and finally Hygiene, in which I would include Elementary Physiology. I do not think that the subject of Sex Hygiene, as such, should be dealt with. The course should be merely Hygiene as defined above. The introduction of the word "sex" tends to make the child introspective and curious, and the reaction on the mind under these conditions is not likely to be beneficial.

At one time I had thought it possible that the subject of Human Embryology might be simply dealt with, and the physiological processes resulting from the fusion of the male and female elements of reproduction and the development of the fertilised ovum explained. I am of opinion now that this is not practical in the elementary schools, as some children are without the necessary rudimentary knowledge on which to superimpose additional information.

As a further adjunct to Sex Hygiene, children in elementary schools should be taught the Care of the Body. Well-planned courses of Physical Training should be in operation from the lowest to the highest classes, not with the military idea in view, but for the purpose of stimulating the child to become an alert, upright, and vigorous unit in society, so that the race may be improved. The child, on leaving school, should be turned out, as it were, the complete athlete-physically, morally, and intellectually-well trained and equipped for the battle of life.

Round about the age of $I 6$ years, I think the subject of Sex Hygiene as a separate subject could be dealt with. Then I think the essential facts of reproduction could be stated in quite a plain way, for it is much better that these should be learned in a healthy and clean atmosphere than under obscure and perhaps obscene circumstances. Even the marriage relationship might be touched upon at these ages with great advantage to marital happiness and domestic felicity and society generally.

In all that I have said I would make it clear that I am of opinion that upon every occasion the man should speak to the boy and the woman to the girl on sex matters, and from this position I do not exclude the doctor. 